\title{
BALI DALAM PENGEMBANGAN PENGOBATAN TRADISIONAL KOMPLEMENTER \\ (Kajian Yuridis Peraturan Menteri Kesehatan Republik Indonesia Nomor 15 Tahun 2018 Tentang Penyelenggaraan Pelayanan Kesehatan Tradisional Komplementer)
}

\author{
I Nyoman Bagiastra1, I Ketut Sudantra ${ }^{2}$ \\ ${ }^{12}$ Fakultas Hukum, Universitas Udayana, Indonesia
}

Keywords:

traditional; complementary

medicine; usadha
Kata Kunci:

pengobatan tradisional; komplementer; usadha

\section{ABSTRACT}

Abstract: Traditional medicine by the people in several regions in Indonesia is very diverse. Communities in a particular area have different ways and techniques in traditional medicine, this is because culture and understanding and also the biodiversity found in the environment in which they live and the local wisdom they have is the cause of the emergence of various cultural products. Given that Bali has a culture related to the understanding of traditional medicine since ancient times, inherited from generation to generation, it has the potential to carry out complementary traditional medicine that has local wisdom. Usadha was populist in Bali carried out by a balian. There are several types of balian that are contained in the palm bodon ejection in accordance with the field and purpose. Normatively, the government has issued Regulation of the Minister of Health of the Republic of Indonesia Number 15 of 2018 concerning the Implementation of Complementary Traditional Health Services as a basis for implementing complementary traditional medicine. There are provisions that need to be studied and criticized so that they do not have the potential to hinder if Bali carries out complementary traditional medicine services in the future.

\begin{abstract}
Abstrak: Pengobatan tradisional oleh masyarakat yang ada dibeberapa daerah di Indonesia sangat beragam. Masyarakat disuatu daerah tertentu memiliki cara dan teknis yang berbeda-beda dalam pengobatan tradisionalnya, hal ini dikarenakan kebudayaan serta pemahaman dan juga keanekaragaman hayati yang terdapat dilingkungan tempat mereka hidup serta kearifan lokal yang mereka miliki menjadi penyebab munculnya bermacam-macam produk budaya. Mengingat Bali memiliki kebudayaan terkait pemahaman pengobatan tradisional sejak jaman dahulu yang diwariskan secara turun temurun, sangat berpotensi untuk melaksanakan pengobatan tradisional komplementer yang berkearifan lokal setempat. Usadha secara populis di Bali dilakukan oleh seorang balian. Terdapat beberapa jenis balian yang dimuat dalam lontar bodha kocapi sesuai dengan bidang dan tujuannya. Secara normatif, pemerintah telah mengeluarkan Peraturan Menteri Kesehatan Republik Indonesia Nomor 15 Tahun 2018 Tentang Penyelenggaraan Pelayanan Kesehatan Tradisional Komplementer sebagai landasan dalam pelaksanaan pengobatan tradisional komplementer. Terdapat ketentuan yang sekiranya perlu dikaji dan dikritisi agar tidak berpotensi menghambat bilamana Bali melaksanakan pelayanan pengobatan tradisional komplementer secara menyeluruh kelak.
\end{abstract}

Correspondance address:

E-mail: nyomanbagiastra@unud.ac.id (I Nyoman Bagiastra) 


\section{Pendahuluan}

Kesehatan merupakan suatu hal yang mendasar serta fundamental yang tercermin dalam Hak Asasi Manusia dan salah satu unsur kesejahteraan yang harus diwujudkan sesuai dengan cita-cita bangsa Indonesia sebagaimana dimaksud dalam Pancasila dan Undang-Undang Dasar Negara Republik Indonesia tahun 1945. Ciri dari konsep negara kesejahteraan (welfare state) disebutkan bahwa setiap warga Negara berhak atas kesehatan fisik dan mental termasuk fasilitas dan pelayanan yang diselenggarakan oleh Negara dan instansi yang ditunjuk oleh Negara, termasuk masyarakat miskin yang notabene merupakan warga mayoritas penduduk Indonesia. Oleh karena itu, usahausaha manusia untuk upaya perlindungan diri dan penyembuhan penyakit selalu menjadi prioritas untuk diupayakan.

Bangsa Indonesia merupakan bangsa yang kaya akan keanekaragaman budaya dan kearifan lokal yang tercermin dalam pikiran, sikap, tindakan dan hasil budaya itu sendiri (budaya material) (Liliweri, 2003). Masyarakat Indonesia yang terdiri dari berbagai suku dan agama yang tersebar pada berbagai kepulauan di seluruh Indonesia, memiliki banyak sekali produk budaya terutama yang berhubungan dengan kesehatan tradisional. Salah satunya adalah budaya yang berhubungan dengan kesehatan terwujud dalam bentuk pengobatan tradisional dan cara tradisional yang digunakan masyarakat untuk mengatasi permasalahan mereka dibidang kesehatan. Hal ini jelas dimuat dalam ketentuan Undang-undang No. 36 tahun 2009, pasal 59 menyatakan berdasarkan cara pengobatannya, pelayanan kesehatan tradisional terbagi menjadi pelayanan kesehatan tradisional yang menggunakan keterampilan dan pelayanan kesehatan tradisional yang menggunakan ramuan.

Pengobatan tradisional oleh masyarakat yang ada dibeberapa daerah di Indonesia sangat beragam. Masyarakat disuatu daerah tertentu memiliki cara dan teknis yang berbeda-beda dalam pengobatan tradisionalnya, hal ini dikarenakan kebudayaan serta pemahaman dan juga keanekaragaman hayati yang terdapat dilingkungan tempat mereka hidup serta kearifan lokal yang mereka miliki menjadi penyebab munculnya bermacam-macam produk budaya.

Keanekaragaman hayati yang terdapat dilingkungan mereka hidup menjadi sumber alam yang sangat potensial untuk membuat obat-obat tradisional yang mampu menyelesaikan permasalahan kesehatan mereka. Beberapa contoh obat tradisional yang digunakan di masyarakat tertentu seperti: masyarakat Papua menggunakan zodia yang merupakan tanaman perdu untuk mengusir nyamuk malaria. Masyarakat jawa menggunakan tanaman tapak dara untuk mengobati penyakit diabetes, hipertensi, leukimia, mengobati luka baru, obat bengkak dan obat bisul. Badan kesehatan Dunia PBB (World Health Organization) menunjukkan kepedulian tentang perkembangan dan pengembangan pengobatan tradisional. Bahkan, badan dunia ini sudah mengeluarkan buku panduan umum penelitian pengobatan tradisional. Dalam buku panduan ini, dikemukakan metodologi penelitian dan evaluasi penelitian terhadap jenis pengobatan tradisional. Sementara jenis pengobatan alternative yang dikembangkan dan dijadikan kajiannya, dikelompokkan menjadi dua jenis, yaitu pengobatan berdasarkan herbal dan terapi yang berdasarkan prosedur tradisional, yang termasuk ke dalam pengobatan alternative herbal, yaitu penggunaan bahan asli tanaman seperti bunga, buah-buahan, akar, atau bagian lain dari tumbuhan yang digunakan untuk pengobatan. Pengolahan herbal (herbal preparation). Pengolahan tumbuhan dilandaskan pada produk tumbuhan yang sudah diselesaikan, atau beberapa produk pengolahan tanaman hasil dari ekstrasi, pelarutan fraksianisasi, purifikasi, konsentrasi atau proses pengolahan fisikawi. Jenis pengobatan alternative yang kedua adalah terapi. Terapi yang dilandaskan pada prosedur tradisional adalah terapi-terapi yang digunakan dengan teknik bervariasi, terutama yang tanpa menggunakan medikasi. Misalnya akupuntur dan teknik-teknik chiropractic, osteopathy, manual therapies, qigong, tai ji, yoga, naturopathy, thermal medicine dan terapi fisik lainnya. (Darmastuti. R \& Sari. DK, 2011).

Sistem pelayanan kesehatan merupakan bagian penting dalam meningkatkan derajat kesehatan. Dengan adanya sistem kesehatan ini tujuan pembangunan dapat tercapai efektif, efisien, dan tepat sasaran. Keberhasilan sistem pelayanan kesehatan bergantung pada berbagai komponen 
yang ada baik dana, fasilitas penunjang maupun sumber daya manusia yang ada, dalam hal ini perawat, dokter, radiologi, ahli fisioterapi, ahli gizi, dan tim kesehatan lain (Avonina, S, 2006).

WHO merekomendasi penggunaan obat tradisional termasuk obat herbal dalam pemeliharaan kesehatan masyarakat, pencegahan dan pengobatan penyakit, terutama untuk kronis, penyakit degeneratif dan kanker. Hal ini menunjukan dukungan WHO untuk "back to nature" yang dalam hal yang lebih menguntungkan. Untuk meningkatkan keselektifan pengobatan dan mengurangi pengaruh musim dan tempat asal tanaman terhadap efek, serta lebih memudahkan standarisasi bahan obat maka zat aktif diekstraksi lalu dimurnikan sampai diperoleh zat murni. Di Indonesia dari tahun ke tahun terjadi peningkatan produksi obat tradisional serta semakin banyaknya praktik pelayanan kesehatan pengobatan tradasional.

UU No. 36 Tahun 2009 Tentang Kesehatan, pada bagian ketiga Pasal 59 (1) Berdasarkan cara pengobatannya, pelayanan kesehatan tradisional terbagi menjadi: a. pelayanan kesehatan tradisional yang menggunakan keterampilan; dan b. pelayanan kesehatan tradisional yang menggunakan ramuan. (2) Pelayanan kesehatan tradisional sebagaimana dimaksud pada ayat (1) dibina dan diawasi oleh Pemerintah agar dapat dipertanggungjawabkan manfaat dan keamanannya serta tidak bertentangan dengan norma agama. (3) Ketentuan lebih lanjut mengenai tata cara dan jenis pelayanan kesehatan tradisional sebagaimana dimaksud pada ayat (1) diatur dengan Peraturan Pemerintah. Pasal 60 (1) Setiap orang yang melakukan pelayanan kesehatan tradisional yang menggunakan alat dan teknologi harus mendapat izin dari lembaga kesehatan yang berwenang. (2) Penggunaan alat dan teknologi sebagaimana dimaksud pada ayat (1) harus dapat dipertanggungjawabkan manfaat dan keamanannya serta tidak bertentangan dengan norma agama dan kebudayaan masyarakat. Pasal 61 (1) Masyarakat diberi kesempatan yang seluas-luasnya untuk mengembangkan, meningkatkan dan menggunakan pelayanan kesehatan tradisional yang dapat dipertanggungjawabkan manfaat dan keamanannya. (2) Pemerintah mengatur dan mengawasi pelayanan kesehatan tradisional sebagaimana dimaksud pada ayat (1) dengan didasarkan pada keamanan, kepentingan, dan perlindungan masyarakat.

Tahun 2018 Pemerintah mengeluarkan Peraturan Menteri Kesehatan Republik Indonesia Nomor 15 Tahun 2018 Tentang Penyelenggaraan Pelayanan Kesehatan Tradisional Komplementer. Peraturan ini merupakan teknis dalam penyelenggraraan terkait dengan pelayanan kesehatan tradisional komplementer.

Bali merupakan daerah yang sangat potensial dalam pengembangan pengobatan tradisional komplementer. Bali pada khususnya masih memiliki budaya pengobatan yang ternyata cukup manjur dan masih dipercayai oleh masyarakatnya untuk menanggulangi penyakit yang ada. Peninggalan budaya ini hendaknya tetap dipelihara dan dilestarikan seutuhnya lahir dan bathin. Dewasa ini pengetahuan orang Bali tentang penyembuhan (usada) masih mempunyai kehidupan yang sungguhsungguh berhubungan dengan agama Hindu, hanya sedikit orang yang mau mempelajari secara seksama. Hal ini disebabkan bahwa masyarakat Bali mengalami hambatan sosio-psikologis untuk mempelajari lontar (usada dan tutur).

Secara pemahaman pasca dikeluarkannya Peraturan Menteri Kesehatan Republik Indonesia Nomor 15 Tahun 2018 Tentang Penyelenggaraan Pelayanan Kesehatan Tradisional Komplementer, maka perlu sekiranya suatu kajian baik secara filosofis sosiologis dan yuridis dalam penyelenggaraan pengobatan tradisional komplementer di Bali yang berkesesuaian dengan peraturan tersebut.

\section{Metode Penelitian}

Dalam penelitian ilmiah ini termasuk dalam didukung oleh metode tertentu sehingga penelitian tersebut dapat berlangsung secara terencana dan teratur. Van Peursen menterjemahkan pengertian metode secara harfiah, mula-mula metode diartikan sebagai suatu jalan yang harus ditempuh menjadi penyelidikan atau penelitian, berlangsung menurut suatu rencana tertentu (Johnny Ibrahim, 2006). Penelitian adalah merupakan suatu kegiatan ilmiah yang berkaitan dengan analisa dan kontruksi yang dilakukan secara metodologis, sistematis, dan konsisten (Soerjono 
Soekanto, 1984). Sementara penelitian hukum adalah suatu proses untuk menemukan aturan hukum, prinsip-prinsip hukum, maupun doktrin-doktrin hukum, guna menjawab isu hukum yang dihadapi, sehingga penelitian hukum dilakukan untuk menghasilkan argumentasi, teori atau konsep baru sebagai preskripsi dalam penyelesaian masalah yang dihadapi (Peter Mahmud Marzuki, 2009).

Penelitian yang dilakukan kaitannya dengan penelitian ini termasuk jenis penelitian hukum normatif, yaitu penelitian hukum kepustakaan atau penelitian hukum yang didasarkan pada data sekunder (Soerjono Soekanto, 1985).

Dengan demikian dapat dipahami bahwa penelitian hukum normatif memfokuskan obyek kajian pada ketentuan-ketentuan hukum positif, lalu mengarah pada makna dari azas hukum. Penelitian hukum normatif terhadap pengkajian (analisis) dimulai dari perangkat-perangkat pasalpasal hukum positif terkandung konsep-konsep eksplanasi dan sifat dari permasalahan penelitian. Selanjutnya mendalami lapisan ilmu hukum (dogmatik hukum, teori hukum, dan filsafat hukum) (Hadin Mudjad HM. dan Nunuk Nuswardani, 2012).

Penelitian kepustakaan yaitu penelitian yang dilakukan dengan mencari, mempelajari dan mengumpulkan data sekunder yang berhubungan dengan obyek penelitian, dengan bantuan buku, literatur, peraturan perundang undangan dan dokumen-dokumen yang terdiri dari bahan-bahan sebagai berikut.

1. Bahan Hukum Primer

Bahan hukum primer yaitu bahan hukum yang mengikat (Soerjono Soekanto dan Sri Mamudji, 2006). Bahan hukum primer dalam penelitian ini terdiri atas :

a. UU No. 36 Tahun 2009 Tentang Kesehatan

b. Peraturan Menteri Kesehatan Republik Indonesia Nomor 15 Tahun 2018 Tentang Penyelenggaraan Pelayanan Kesehatan Tradisional Komplementer.

2. Bahan Hukum Sekunder

"Bahan hukum sekunder ialah bahan hukum yang mejelaskan bahan hukum primer" (Peter Mahmud Marzuki, 2005). Terutama buku-buku hukum termasuk skripsi, thesis, disertasi hukum dan jurnal jurnal hukum,(termasuk yang on-line). Bahan hukum sekunder berguna untuk meberikan petunjuk kearah mana peneliti akan melangkah.

3. Bahan Hukum Tersier

"Bahan hukum tersier adalah bahan hukum yang memberikan petunjuk maupun penjelasan terhadap bahan hukum primer dan bahan hukum sekunder", yang terdiri dari Kamus Besar Bahasa Indonesia, Kamus Hukum Belanda-Indonesia, Kamus Inggris-Indonesia.

Untuk memperoleh data yang diperlukan dalam penelitian kepustakaan, maka dilakukan studi dokumen yaitu mempelajari bahan-bahan hukum primer, sekunder dan tersier.

\section{Hasil dan Pembahasan}

\section{Pelayanan Kesehatan Tradisional}

Pelayanan kesehatan tradisional merupakan suatu pelayanan dimana pengobatan dan/atau perawatan yang diberikan dengan cara dan obat yang mengacu pada pengalaman dan keterampilan turun temurun secara empiris yang dapat dipertanggungjawabkan dan diterapkan sesuai dengan norma yang berlaku di masyarakat. Berdasarkan ketentuan tersebut dapat dijabarkan bahwa pengertian pelayanan kesehatan tradisional mengandung persyaratan sebagai berikut.

1. Menggunakan cara atau obat.

2. Berdasarkan pengalaman dan ketrampilan yang turun-temurun.

3. Dapat dipertanggung jawabkan secara empiris.

4. Penerapannya sesuai dengan norma yang berlaku dimasyarakat.

Oleh karena itu dapat disimpulkan bahwa tidak semua jenis pengobatan atau perawatan yang dilakukan Berdasarkan pengalaman dan ketrampilan masuk dalam katagori yang dimaksudkan 
oleh Undang-Undang, melainkan harus memenuhi uji empirik dan tidak melanggar norma yang berlaku di masyarakat.

Saat ini, keberadaan pengobatan tradisional (Battra) di Indonesia cukup diakui dan banyak dimanfaatkan oleh masyarakat untuk memenuhi kebutuhan akan kesehatan. Pemanfaatan pengobatan tradisional pada umumnya lebih diutamakan sebagai upaya pengobatan suatu penyakit. Dalam pelayanan kesehatan, Battra merupakan salah satu pilihan bagi masyarakat dalam mencari pemecahan masalah kesehatan. Masyarakat memilih cara pengobatan tradisional pada umumnya karena obat tradisional mudah diperoleh dan biayanya relatif murah dibandingkan pengobatan modern.

Untuk dapat dimanfaatkannya secara luas oleh masyarakat, pengobatan tradisional dalam pelayanan kesehatan, banyak yang harus diperhatikan. Diantaranya, pelayanan kesehatan: 1) Bersifat jelas. Artinya dapat diukur dengan baik, termasuk ukuran terhadap penyimpanganpenyimpangan yang mungkin terjadi. Penyimpangan yang terjadi bisa berasal dari pelaksana pengobatan tradisional tersebut ataupun pemerintah seperti kurangnya pengawasan dari pemerintah. 2) Masuk akal. Suatu standar yang tidak masuk akal, bukan saja akan sulit dimanfaatkan tetapi juga akan menimbulkan frustasi bagi para professional atau praktisi pengobatan. Setiap metode atau cara yang digunakan dalam pengobatan harus dapat dipertanggungjawabkan. 3) Mudah dimengerti. Suatu standar yang tidak mudah dimengerti juga akan menyulitkan tenaga pelaksana sehingga sulit terpenuhi untuk suatu pelayanan kesehatan. 4) Dapat dipercaya. Tidak ada gunanya menentukan standar yang sulit karena tidak akan mampu tercapai dalam pemenuhan pelayanan kesehatan. Karena itu sering disebutkan, dalam menentukan standar, salah satu syarat yang harus dipenuhi ialah harus sesuai dengan kondisi organisasi yang dimiliki. Dapat dipercaya kebenarannya agar bermanfaat untuk masyarakat. 5) Absah. Artinya ada hubungan yang kuat dan dapat didemintrasikan antara standar dengan mutu pelayanan yang diwakilinya. 6) Meyakinkan. Artinya mewakili persyaratan yang ditetapkan. Apabila tingkat keyakinan suatu pelayanan terlalu rendah akan menyebabkan persyaratan lainnya menjadi tidak berarti dan tidak bisa dterima dimasyarakat. 7) Mantap, Spesifik dan Eksplisit. Artinya tidak terpengaruh oleh perubahan oleh waktu, bersifat khas dan gamblang. Dengan persyaratan ini diharapkan, bukan saja mutu pengobatan tradisional akan dapat ditingkatkan, tapi yang penting lagi munculnya berbagai efek samping yang secara medis tidak dapat dipertanggung jawabkan, akan dapat dihindari. Akan tetapi, yang terjadi saat ini banyaknya bermunculan konsep pengobatan tradisional dengan supranatural. Dimana konsep ini standarnya satu sama lain terlihat berbeda dengan standar pengobatan seharusnya dan diragukan kejelasan, kepercayaannya, keabsahan, keyakinannya sehingga menyebabkan standarisasi suatu pelayanan yang baik akan sulit dilakukan. Untuk itu mengharuskan pemerintah untuk lebih mencermati dan melakukan pengawasan terhadap para praktisi pelayanan kesehatan sebagai wujud perlindungan pemerintah kepada warga negaranya (Jusuf Hanafiah, Amri Amir, 2007).

Tanggungjawab pemerintah ini diatur dalam Pasal 14-20 Undang-undang No.36 Tahun 2009 Tentang Kesehatan. Tanggungjawab pemerintah terhadap pelayanan kesehatan tradisional sendiri diperjelas pada Pasal 59 Undang-undang No.36 Tahun 2009 Tentang Kesehatan bahwa berdasarkan cara pengobatannya, pelayanan kesehatan tradisional terbagi menjadi pelayanan kesehatan tradisional yang menggunakan keterampilan; dan pelayanan kesehatan tradisional yang menggunakan ramuan.

Pelayanan kesehatan tradisional ini dibina dan diawasi oleh Pemerintah agar dapat dipertanggungjawabkan manfaat dan keamanannya serta tidak bertentangan dengan norma agama. Ketentuan lebih lanjut mengenai tata cara dan jenis pelayanan kesehatan tradisional baik itu yang menggunakan keterampilan maupun ramuan diatur dengan Peraturan Pemerintah. Pasal 60 Undangundang No.36 Tahun 2009 Tentang Kesehatan memuat bahwa setiap orang yang melakukan pelayanan kesehatan tradisional yang menggunakan alat dan teknologi harus mendapat izin dari lembaga kesehatan yang berwenang. Penggunaan alat dan teknologi tersebut harus dapat dipertanggungjawabkan manfaat dan keamanannya serta tidak bertentangan dengan norma agama dan kebudayaan masyarakat. Sedangkan pada Pasal 61 Undang-undang No.36 Tahun 2009 Tentang Kesehatan disebutkan bahwa Masyarakat diberi kesempatan yang seluas-luasnya untuk 
mengembangkan, meningkatkan dan menggunakan pelayanan kesehatan tradisional yang dapat dipertanggungjawabkan manfaat dan keamanannya. Pemerintah wajib mengatur dan mengawasi pelayanan kesehatan tradisional tersebut dengan didasarkan pada keamanan, kepentingan, dan perlindungan masyarakat.

\section{Bali Dalam Pengembangan Pengobatan Tradisional Komplementer}

Peraturan Menteri Kesehatan Republik Indonesia Nomor 15 Tahun 2018 Tentang Penyelenggaraan Pelayanan Kesehatan Tradisional Komplementer telah dikeluarkan oleh Pemerintah. Terdapat beberapa ketentuan yang sekiranya perlu dipersiapkan apabila Bali secara sungguh-sungguh dalam pelaksanaannya.

Dalam ketentuan umum terdapat hal-hal penting yang sekiranya perlu diperhatikan, disebutkan bahwa, Pelayanan Kesehatan Tradisional adalah pengobatan dan/atau perawatan dengan cara dan obat yang mengacu pada pengalaman dan keterampilan turun temurun secara empiris yang dapat dipertanggungjawabkan dan diterapkan sesuai dengan norma yang berlaku di masyarakat. Pelayanan Kesehatan Tradisional Komplementer adalah penerapan kesehatan tradisional yang memanfaatkan ilmu biomedis dan biokultural dalam penjelasannya serta manfaat dan keamanannya terbukti secara ilmiah. Tenaga Kesehatan Tradisional adalah setiap orang yang mengabdikan diri dalam bidang kesehatan tradisional serta memiliki pengetahuan dan/atau keterampilan melalui pendidikan di bidang kesehatan tradisional yang untuk jenis tertentu memerlukan kewenangan untuk melakukan upaya kesehatan tradisional. Klien adalah setiap orang yang melakukan konsultasi masalah kesehatan pada Pelayanan Kesehatan Tradisional Komplementer. Griya Sehat adalah Fasilitas Pelayanan Kesehatan Tradisional yang menyelenggarakan perawatan atau pengobatan tradisional dan komplementer oleh Tenaga Kesehatan Tradisional. Obat Tradisional adalah bahan atau ramuan bahan yang berupa bahan tumbuhan, bahan hewan, bahan mineral, sediaan sarian (galenik), atau campuran dari bahan tersebut yang secara turun temurun telah digunakan untuk pengobatan dan dapat diterapkan sesuai dengan norma yang berlaku di masyarakat. Surat Tanda Registrasi Tenaga Kesehatan Tradisional yang selanjutnya disingkat STRTKT adalah bukti tertulis pemberian kewenangan untuk memberikan Pelayanan Kesehatan Tradisional Komplementer. Surat Izin Praktik Tenaga Kesehatan Tradisional, yang selanjutnya disingkat SIPTKT adalah bukti tertulis yang diberikan kepada Tenaga Kesehatan Tradisional dalam pemberian Pelayanan Kesehatan Tradisional Komplementer. Instansi Pemberi Izin adalah instansi atau satuan kerja yang ditunjuk oleh pemerintah daerah kabupaten/kota untuk menerbitkan izin sesuai dengan ketentuan peraturan perundang-undangan. Organisasi Profesi Tenaga Kesehatan Tradisional yang selanjutnya disebut sebagai Organisasi Profesi adalah wadah untuk meningkatkan dan/atau mengembangkan pengetahuan dan keterampilan, martabat, dan etika profesi Tenaga Kesehatan Tradisional.

Dalam penelitian ini, yang menjadi fokus pembahasan adalah pada ketentuan pasal 4

yang disebutkan bahwa, Pasal 4 (1) Pelayanan Kesehatan Tradisional Komplementer harus memenuhi Kriteria: a. dapat dipertanggungjawabkan keamanan dan manfaatnya mengikuti kaidahkaidah ilmiah bermutu dan digunakan secara rasional dan tidak bertentangan dengan norma agama dan norma yang berlaku di masyarakat; b. tidak membahayakan kesehatan Klien; c. memperhatikan kepentingan terbaik Klien; dan d. memiliki potensi pencegahan penyakit, peningkatan kesehatan, penyembuhan, pemulihan kesehatan, dan meningkatkan kualitas hidup Klien secara fisik, mental, dan sosial. (2) Tidak bertentangan dengan norma agama sebagaimana dimaksud pada ayat (1) huruf a, berupa tidak memberikan pelayanan dalam bentuk mistik/klenik, dan/atau menggunakan pertolongan makhluk gaib. (3) Tidak bertentangan dengan norma yang berlaku di masyarakat sebagaimana dimaksud pada ayat (1) huruf a berupa tidak melanggar nilai-nilai kesusilaan, kesopanan, hukum, dan budaya.

Bilamana dicermati khususnya ketentuan pasal 4 ayat 2 disebutkan, Tidak bertentangan dengan norma agama sebagaimana dimaksud pada ayat (1) huruf a, berupa tidak memberikan pelayanan dalam bentuk mistik/klenik, dan/atau menggunakan pertolongan makhluk gaib. Bilamana dikaitkan dengan budaya Hindu di Bali, pengobatan tradisional tidak bisa terlepas dari keyakinan 
serta kepercayaan secara turun temurun dengan menggunakan berbagai metode pendekatan dalam pelaksanaannya.

Ketentuan pemaknaan secara frase terkait berupa tidak memberikan pelayanan dalam bentuk mistik/klenik, dan/atau menggunakan pertolongan makhluk gaib, perlu sekiranya dijelaskan secara tegas. Sebab hal ini berpotensi menghambat bilamana Bali berkeinginan untuk melaksanakan pengobatan tradisional secara holistic sesuai dengan keyakinannya yang telah diwariskan secara turun temurun.

Di Bali dikenal istilah usadha, dan secara populis di masyarakat Bali disebut dengan balian. Balian, waidhya, pengobat (battra = pengobat tradisional), dukun, atau tabib. Berdasarkan atas kekuatan yang dimiliki dibagi pula atas tiga kelompok. Ketiga kelompok balian atau dukun ini, adalah balian lanang (maskulin, sifat kejantanan), balian wadon (feminism, sifat kebetinaan), dan balian kedi (netral, sifat kebancian). Istilah ini bukanlah berarti balian lanang itu adalah balian yang berjenis kelamin laki-laki, balian wadon bukanlah balian yang berjenis kelamin wanita, dan balian kedi itu tidaklah berarti balian yang berjenis kelamin laki-laki maupun wanita. Jadi balian merupakan orang yang mempunyai kekuatan untuk menyembuhkan penyakit seseorang.

Menurut I Made Sukantra dalam Kamus Bali Indonesia: bidang istilah pengobatan tradisional Bali (USADA), ajaran Hindu çiwa Siddanta menyatakan bahwa Ida Sang Hyang Widhi atau Batara çiwa yang menciptakan semua yang ada di jagat raya ini, beliau pula yang mengadakan penyakit (gering, wyadhi), obat (tamba, ubad), dan pengobat (balian) hidup dan mati juga kehendak beliau. Utpatti (lahir), Sthiti (hidup), dan Pralina (mati). Laku balian yang diwacanakan dalam lontar Bodha Kecapi adalah Madewasraya usaha mistik-magis seorang penganut Siwa Tantrik untuk memohon pertolongan dewa agar dapat menjadi balian sejati. Untuk menjadi seorang balian harus berani melaksanakan mati raga di setra pangesengan (tempat pembakaran mayat). Bila orang berhasil mati raga maka ia mendapat anugrah Tuhan. Anugrah-Nya dapat berupa kesiddian (kekuatan adikodrat).

Dharma sesana balian dapat disamakan dengan etika balian, sesana berarti tingkah laku, kewajiban. Sedangkan etika, yang berasal dari kata ethos (Yunani) berati ilmu pengetahuan tentang asas moral. Dharma sesana di dalam bahasa Indonesia dapat disejajarkan dengan tata susila, yakni dasar kebaikan yang menjadi pedoman dalam kehidupan manusia, kewajiban yang harus dipenuhi selaku anggota masyarakat. Manusia harus melakukan dharma sesana jika ingin kehidupannya mencapai kebahagiaan. Dia harus menyesuaikan diri dengan lingkungannya baik dengan buana alit maupun dengan buana agung. Di dalam setiap agama pedoman dharma sesana ini pasti ada karena ajaran yang baik selalu bersifat universal. Manusia apapun pekerjaannya apalagi sebagai balian bila ingin hidup sejahtera harus berpijak pada patokan yang pasti, yaitu dharma sesana. Balian yang bekerja menghadapi manusia, memerlukan dharma sesana yang baku, yang dapat diikuti dan ditaati oleh semua balian sebagai pedoman dalam melaksanakan profesinya.

Balian Berdasarkan tujuannya dapat dijelaskan sebagai berikut. Balian Penengen adalah balian yang tujuannya mengobati orang yang sakit sehingga menjadi sembuh. Balian ini sering pula disebut Balian Ngardi Ayu (dukun kebaikan). Balian ini pada umumnya bersifat ramah, terbuka, penuh wibawa dan suka menolong. Siapapun akan ditolongnya tidak membedakan apakah dia orang baik atau orang jahat, orang yang miskin atau kaya semua dilayani sesuai dengan penyakit yang dideritanya. Balian Pengiwa adalah balian yang tujuannya membuat orang yang sehat menjadi sakit dan orang yang sakit bertambah menjadi sakit, bahkan sampai meninggal. Itulah sebabnya balian tipe ini sering disebut balian aji wegig, dukun yang menjalankan kekuatan membencanai orang lain, berbuat jahil, usil, terhadap orang lain. Balian jenis ini amat sukar dilacak, pekerjaannya penuh rahasia, tertutup dan misterius. Sering pula balian ini mengganggu balian penengen pada waktu pengobati orang sakit sehingga tidak sembuh-sembuh, jahil dan usil. Merupakan sisi lain dari aji wegig ini mendatangkan hujan pada waktu orang sedang melakukan upacara, menahan hujan (nerang) pada waktu orang bercocok tanam, serta menguji kesaktian dengan balian lainnya adalah kegemaran dari balian pengiwa ini. Di samping itu, balian ini juga mempunyai kemampuan untuk menyembuhkan, terutama orang yang kena aji wegignya sendiri, atau diri orang lain.

Balian dilihat dari cara mereka mendapatkan keahliannya: Balian kapican adalah orang yang mendapat benda bertuah yang dapat dipergunakan untuk mengobati orang yang sakit. Benda 
bertuah ini disebut Pica. Pica ini dapat berupa keris kecil, batu permata, pis bolong, batu mekocok, tulang, gigi, besi atau logam lainnya, gigi kilap, serta benda lain yang bentuknya aneh. Ada malahan yang berupa binatang seperti kucing, anjing, burung, ular atau binatang lainnya. Benda pica ini diperoleh biasanya melalui petunjuk di alam mimpi. Di dalam mimpinya dijelaskan tentang tempat benda tersebut dan kasiatnya untuk pengobatan. Kalau berupa binatang maka ia akan datang sendiri atau dijemput disuatu tempat. Dengan mempergunakan benda-benda atau binatang pica ini, dia mampu menyembuhkan orang yang sakit sejak itu mereka disebut Balian Kapican, dukun yang mendapat pica atau kapican oleh suatu kekuatan gaib. Jika pica itu berbentuk permata, umpamanya dengan cara menaruh batu permata itu ditempat yang dirasakan sakit oleh pasiennya, kadangkadang disertai dengan mengosok-gosokkan permata itu di badan si sakit, maka penyakit orang tersebut akan sembuh. Atau dengan cara memasukkan permata itu kedalam air kemudian air itu diminum oleh si sakit dan sembuhlah penyakitnya. Ada pula yang disertai dengan pembacaan mantra dengan disertai sesajen dalam proses pengobatannya. Balian Katakson balian jenis ini balian yang mendapatkan keahlian melalui taksu. Taksu adalah kekuatan gaib yang masuk kedalam diri seseorang dan mempengaruhi orang tersebut. Baik secara berpikir, berbicara, maupun tingkah lakunya karena kemasukan taksu inilah orang tersebut mempunyai kemampuan untuk mengobati orang sakit. Itulah sebabnya dia dinamai Balian Katakson, dukun yang ketaksuan, kemasukan taksu (kesurupan), dia berfungsi sebagai mediator penghubung.

Cara masuknya taksu ke dalam diri balian ini tidaklah sama antara balian yang satu dengan balian lainnya. Beberapa dari mereka baru kemasukan taksu atau kesurupan, setelah menghaturkan sembah dihadapan di sebuah pelinggih atau dihadapan sajen tertentu. Adapula dengan memegang sebuah dupa yang menyala, duduk bersila dan memohon kepada Hyang Widhi, kemudian taksu masuk ke dalam dirinya. Balian katakson ini sering pula disebut balian tatakson, yakni dukun ketaksuan (tempat taksu). Balian usada adalah seseorang yang dengan sadar belajar tentang ilmu pengobatan, baik melalui guru waktera, belajar pada seorang balian yang telah mahir dalam ilmu pengobatan, maupun belajar sendiri melalui lontar usada. Karena untuk menjadi balian tipe ini melalui proses belajar, maka orang barat menyebut balian jenis ini dengan julukan Dokter Bali. Mengenai proses seseorang menjadi balian usada dapat dibaca dalam lontar boda kecapi, usada kalimosadha, dan usada sari. Setelah tamat mempelajari Katikelaning Genta Pinata Pitu dan sastra sanga, maka dianggap siswa telah bersih jiwa dan raganya. Siswa ini telah hilang kawahnya, yakni keletehan serta kotoran dan keburukan yang ada di dalam dirinya telah musnah. Sekarang dia telah dianggap telah siap untuk diberi pelajaran membaca lontar usada. Balian Campuran adalah campuran antara balian katakson maupun balian kapican yang mempelajari usada. Dengan demikian balian katakson maupun kapican kemampuannya tidak hanya mengandalkan taksu atau pica, tetapi telah bertambah dengan memberikan ramuan obat-obatan berdasarkan lontar usada. Balian tipe ini dapat disebut balian katakson usada atau balian kapican usada. Balian jenis ini juga dikenal dengan istilah balian ngiring pekayunan atau menjadi tapakan Widhi atau tapakan dewa. Pada umumnya, mereka menjadi balian bukanlah atas kemauannya sendiri, tetapi ditunjuk oleh kekuatan gaib. Bila menolak akan tertimpa penyakit, kapongor, atau menjadi gila, pikiran selalu kalut, semua hasil usaha gagal. Hanya dengan mengikuti perintah gaib dia akan kembali normal. Balian seperti ini paling banyak berkembang dan tumbuh subur serta mendapat pasaran. Padahal, keampuhan pengobatannya tidaklah berlangsung lama. Tidak langgeng, hanya bersifat sementara.

Dari penjelasan tersebut diatas, pengobat tradisional di bali yang disebut dengan balian, metode yang digunakan dalam pengobatan disesuaikan dengan keahlian dan fungsinya masingmasing. Ketentuan pasal 4 ayat (2) Tidak bertentangan dengan norma agama sebagaimana dimaksud pada ayat (1) huruf a, berupa tidak memberikan pelayanan dalam bentuk mistik/klenik, dan/atau menggunakan pertolongan makhluk gaib, bisa saja dapat berpotensi menghambat pengembangan pengobatan tradisional di bali secara menyeluruh. Karena apa yang dimaksud dengan pelayanan dalam bentuk mistik/klenik, dan atau menggunakan pertolongan makhluk gaib tidak dijelaskan dengan tegas dalam peraturan tersebut. Pemahaman konsep pengobatan tradisional di bali bilamana dicermati, terdapat unsur-unsur yang melibatkan alam niskala. Alam niskala sangat dekat dengan hal- 
hal yang berbau mistis dan juga melibatkan roh-roh leluhur yang bersifat gaib yang sangat diyakini oleh masyarakat hindu di Bali.

\section{Simpulan}

Salah satu tindakan yang dapat memajukan dan mengembangkan pembangunan adalah melalui perlindungan hukum dalam bidang kesehatan melalui pelayanan kesehatan. Peran pemerintah dalam melakukan pembangunan tersebut sangat penting. Pemerintah diharapkan membuat suatu aturan yang memihak pada masyarakat. Peraturan-peraturan yang dibuat harus dapat menciptakan suatu perlindungan hukum yang tepat bagi masyarakat khusunya para praktisi pemberi pelayanan kesehatan sesuai dengan tujuan dan fungsi hukum yang berlandaskan semangat Pancasila dan Undang-Undang Dasar 1945.

Suatu pusat Pelayanan Kesehatan Tradisional merupakan sarana pelayanan kesehatan yang menyediakan dan menyelenggarakan upaya pelayanan kesehatan dimana pengobatan dan/atau perawatan yang diberikan dengan cara dan obat yang mengacu pada pengalaman dan keterampilan turun temurun dengan melibatkan praktisi kesehatan dibidangnya.

Secara normatif, telah diterbitkan Peraturan Menteri Kesehatan Republik Indonesia Nomor 15 Tahun 2018 Tentang Penyelenggaraan Pelayanan Kesehatan Tradisional Komplementer. Bilamana dicermati isi dari ketentuan beberapa pasal, sekiranya berpotensi menghambat pelaksanannya di Bali. Salah satunya adalah ketentuan pasal 4 (2) Tidak bertentangan dengan norma agama sebagaimana dimaksud pada ayat (1) huruf a, berupa tidak memberikan pelayanan dalam bentuk mistik/klenik, dan/atau menggunakan pertolongan makhluk gaib. Bali yang kaya akan kebudayaan dan pemahaman terkait pengobatan tradisional yang merupakan warisan turun temurun yang dituangkan dalam bentuk ajaran-ajaran wedha maupun lontar, dalam penerapannya yang dilakukan oleh para usadha yang di bali disebut dengan balian, menggunakan metode sesuai dengan kehaliannya masing-masing, dan tidak menutup kemungkinan dalam metode pengobatannya menggunakan alam niskala atau biasanya disebut sebagai alam abstrak, maya, khayal dan tak berwujud (nirupam), namun sebenarnya isinya adalah rasa bakti kepada Tuhan.

Menyikapi temuan ini, maka perlu sekiranya diberikan pemahaman yang jelas dan tegas terkait apa yang dimasudkan dengan pelayanan dalam bentuk mistik/klenik, dan/atau menggunakan pertolongan makhluk gaib dalam ketentuan Peraturan Menteri Kesehatan Republik Indonesia Nomor 15 Tahun 2018 Tentang Penyelenggaraan Pelayanan Kesehatan Tradisional Komplementer agar tidak berpotensi menghambat bilamana bali melaksanakan pengobatan tradisionalnya secara holistik dan menyeluruh berdasarkan pemahaman dan keyakinannya.

\section{Daftar Referensi}

Avonina, S., 2006, Apa Yang Dimaksud Dengan Pengetahuan Tradisional Konvergensi.

Bambang Sunggono, 1997, Metodologi Penelitian Hukum, PT. Raja Grafindo Persada, Jakarta.

Darmastuti, R \& Sari, D.K., 2011, Kekuatan Kearifan Lokal Dalam Komunikasi Kesehatan. Jurnal Komunikasi.

Hadin Mudjad HM. dan Nunuk Nuswardani, 2012, Penelitian Hukum Indonesia Kontemporer, Genta Publishing, Yogyakarta.

I Made Sukantra dalam Kamus Bali Indonesia: bidang istilah pengobatan tradisional Bali (USADA). Jusuf Hanafiah, Amri Amir, 2007. Etika Kedokteran dan Hukum Kesehatan, Edisi 4, Jakarta: EGC. Johnny Ibrahim, 2006, Teori dan Metodologi Penelitian Hukum Normatif, Bayu Publishing, Malang.

Liliweri, A, 2003, Dasar-Dasar Komunikasi Antar Budaya. Yogyakarta: Pustaka Pelajar. 
Peter Mahmud Marzuki, 2005, Penelitian Hukum, Prenada Media, Jakarta.

Peter Mahmud Marzuki, 2009, Penelitian Hukum, Kencana, Jakarta.

Soerjono Soekanto, 1985, Penelitian Hukum Normatif Suatu Tinjauan Singkat, CV. Rajawali.

Soerjono Soekanto dan Sri Mamudji, 2006, Penelitian Hukum Normatif. Jakarta: Raja. Grafindo Persada.

Soerjono Soekanto, 1984, Pengantar Penelitian Hukum, UI Press, Jakarta.

Undang-Undang No. 36 Tahun 2009 Tentang Kesehatan.

Peraturan Menteri Kesehatan Republik Indonesia Nomor 15 Tahun 2018 Tentang Penyelenggaraan Pelayanan Kesehatan Tradisional Komplementer. 